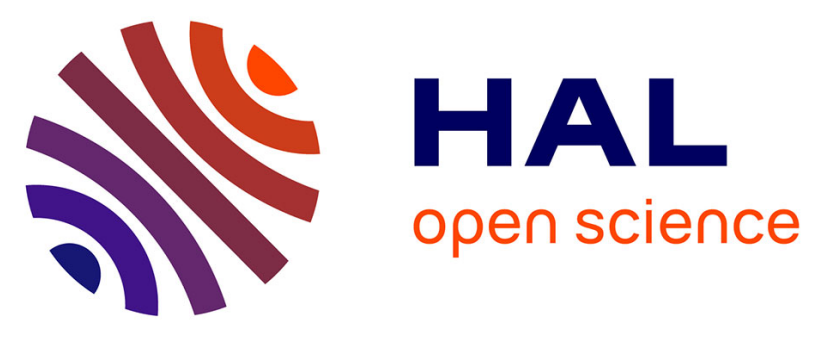

\title{
African Non Human Primates Infected by SIV - Why Dont they Get Sick? Lessons from Studies on the Early Phase of Non-Pathogenic SIV Infection
} Anne-Sophie Liovat, Béatrice Jacquelin, Mickaël Ploquin, Françoise Barré-Sinoussi, Michaela Müller-Trutwin

\section{- To cite this version:}

Anne-Sophie Liovat, Béatrice Jacquelin, Mickaël Ploquin, Françoise Barré-Sinoussi, Michaela MüllerTrutwin. African Non Human Primates Infected by SIV - Why Dont they Get Sick? Lessons from Studies on the Early Phase of Non-Pathogenic SIV Infection. Current HIV Research, 2009, 7 (1), pp.39-50. 10.2174/157016209787048546 . pasteur-01962242

\section{HAL Id: pasteur-01962242}

https: / hal-pasteur.archives-ouvertes.fr/pasteur-01962242

Submitted on 20 Dec 2018

HAL is a multi-disciplinary open access archive for the deposit and dissemination of scientific research documents, whether they are published or not. The documents may come from teaching and research institutions in France or abroad, or from public or private research centers.
L'archive ouverte pluridisciplinaire HAL, est destinée au dépôt et à la diffusion de documents scientifiques de niveau recherche, publiés ou non, émanant des établissements d'enseignement et de recherche français ou étrangers, des laboratoires publics ou privés.

\section{(1)(1) $\$(0)$}

Distributed under a Creative Commons Attribution - NonCommercial - ShareAlikel 4.0 


\section{African non human primates infected by SIV - why don't they get sick? Lessons from studies on the early phase of non-pathogenic SIV infection}

Anne-Sophie Liovat ${ }^{1}$, Béatrice Jacquelin ${ }^{1}$, Mickaël J. Ploquin ${ }^{2}$, Françoise BarréSinoussi $^{1} \&$ Michaela C. Müller-Trutwin ${ }^{1}{ }^{*}$

${ }^{1}$ Institut Pasteur, Unité de Régulations des Infections Rétrovirales, Paris, France; ${ }^{2}$ National Institute for Medical Research, Division of Immunoregulation, London, UK.

*corresponding author : Mailing address : Unité de Régulations des Infections Rétrovirales, Institut Pasteur, 25 rue du Dr Roux, 75724 Paris CEDEX 15, France. Tel +33 (0) 140613969 Fax +33 (0) 1456889 57. E-mail: mmuller@pasteur.fr

Running title: Non-pathogenic SIV infection in African non human primates

Keywords: SIV, African non human primate, immune activation, acute infection, inflammation. 


\begin{abstract}
African non human primates are natural hosts of SIV. The infection is generally nonpathogenic despite high steady-state levels of plasma viral RNA that in HIV-1 and SIVmac infections are associated with progression towards AIDS. The viral loads in the gut also are as high as in pathogenic HIV-1/SIVmac infections; but replication levels are lower in peripheral lymph nodes of chronically infected African green monkeys. There is a transient loss of CD4 ${ }^{+}$ $\mathrm{T}$ cells in the blood in SIVagm and SIVsm infections and an early dramatic and more persistent decrease in the gut. Although SIV in natural hosts is thus cytopathic, the continuous viral replication is not associated with immunopathology. $\mathrm{T} \mathrm{CD}^{+}$cells in blood, lymph nodes and gut manifest no or little increase of cell-death by apoptosis. The lymph node and gut architecture is not disrupted. The most striking difference between non-pathogenic SIV and pathogenic HIV-1/SIVmac infections is the lack of chronic T cell activation. Several studies are currently in progress to determine which factors are involved in the maintenance of the low activation level in the non-pathogenic SIV infections. There are two ways in which this could be achieved: (i) a lack of immune activation induction or (ii) an active downregulation of the immune activation. The arguments in favor of each of these two possible ways of immune activation control will be discussed in view of the most recent data in the literature. A particular focus is put on data on the innate immune system and the timing of induction of immunosuppressive mediators during the early phase of SIV infection.
\end{abstract}




\section{Introduction}

African non human primates (NHP) are natural hosts of the simian immunodeficiency virus (SIV). The first species identified as natural carriers of SIVs were sooty mangabeys (SMs), African green monkeys (AGMs), mandrills and chimpanzees. Today, SIV viruses from more than 30 distinct African NHP species have been reported [1]. The infection of African natural hosts (such as AGMs, SMs and mandrills) is generally non-pathogenic. It is striking that the same virus found in African NHPs can be pathogenic in other species. The African natural hosts of SIV are indeed the animal reservoirs of HIV-1 and HIV-2 [1-3]. Furthermore, SIVmac derives from SIVsm and induces the acquired immunodeficiency syndrome (AIDS) in macaques of Asian origin. Nevertheless, wild strains of SIVsm do not always replicate at high titers in macaques [4]; in vivo passages are often needed for adaptation to the heterologous host [5]. There are signs that HIV-1 has also adapted specifically to humans [6]. Additionally, not all macaque species show a similar susceptibility to SIV infection and AIDS. For instance, SIVagm infection of rhesus macaques does not result in persistent high viremia and AIDS, whereas pigtailed $(\mathrm{Pt})$ macaques infected with a particular strain of SIVagm (ver90) or with SIV l'hoest or SIVsun succumb to AIDS [7, 8]. The pathogenicity also depends on the viral strain. For example, SIVagm.ver155 does not induce AIDS in Pt macaques in contrast to SIVagm.ver90 [9]. These are examples that illustrate that the nonpathogenic issue of the infection is determined by an interplay of both host and virus determinants.

The mechanisms of protection against AIDS have been studied most frequently in AGMs and SMs. Other less commonly studied models include mandrills, chimpanzees and l'Hoest monkeys. Animal models allow to thoroughly study the very early virus-host interactions in blood and tissues. Studies on the acute phase in tissues have been mostly addressed in AGMs, but also in SMs. Both in HIV-1/SIVmac infections, events in the early phase of infection are predictive of the further outcome [10, 11]. Such studies on the early events in African NHP models might therefore reveal important information on the mechanisms that control disease progression. Here we will review the data of the literature on the most relevant differences between non-pathogenic and pathogenic HIV/SIV infections during the chronic phase, and whenever available during the acute phase of infection. 


\section{Do natural hosts of SIV display more efficient anti-viral adaptive immune responses?}

African NHPs show higher number of $\mathrm{CD}^{+}$cells in peripheral blood compared to humans and macaques [12]. It has been suggested that this could confer an advantage to the natural hosts. SIV-specific cell-mediated immune responses in the blood of SIVsm-infected SMs are indeed predominantly mediated by $\mathrm{CD}^{+} \mathrm{T}$ cells $[13,14]$. There is in addition evidence of selective immune pressure on SIVsm [15]. There is, however, no evidence for stronger adaptive immune responses in natural hosts of SIV compared to those animals or individuals that progress to AIDS. Many SIV specific T cells in SMs and AGMs are not polyfunctional with respect to the production of IFN-g, TNF-a, IL-2 and/or MIP-1 $\beta[13,16]$. IL-2 ${ }^{+}$were detected in only a very small percentage of SIV-specific T cells $[13,14]$. The magnitude and breadth of the SIV-specific $\mathrm{T}$ cell responses were either similar or weaker than in HIV1/SIVmac infections $[13,14,16]$. Moreover, the level of viral replication correlated with neither their magnitude nor their breadth $[13,14]$. SMs and AGMs display lower levels of granzyme B positive $\mathrm{T}$ cells than SIVmac infected macaques, suggesting an attenuated effector function $[4,16]$. Only minor changes in the levels of plasma viremia are observed in in vivo $\mathrm{CD}^{+}$cell-depleted SMs [17]. This suggests that $\mathrm{CD}^{+} \mathrm{T}$ cells and NK cells exert limited, if any, direct immune control on SIV replication in SIV-infected SMs. The data on cell-mediated adaptive responses in natural hosts therefore indicate that the absence of AIDS is independent of a robust $\mathrm{T}$ cell response to the virus (Tab.1).

Seroconversion in SIV infected African NHPs generally occurs within 4 to 5 weeks, a similar time frame to SIV-infected macaques $[18,19]$. However, chronically infected SMs seem to display one log lower titers of total antibodies compared to macaques [20, 21]. Surprisingly, the levels of proliferating B cells in germinal centers of peripheral LNs from AGMs and SMs is higher than in macaques during early infection [4, 22]. The biological meaning of this observation is not clear. It might reflect an early B cell dysfunction in pathogenic HIV1/SIVmac infections [23]. Natural hosts develop neutralizing antibodies [24, 25]. It is not clear whether their titers are similar to HIV-1/SIVmac infection because they vary considerably depending on the virus and cells used for the assay [26]. They are probably not more efficient than in humans and macaques since the neutralizing activity against the autologous virus isolates seems to be weak [24]. In addition, a selective lack of anti-p27 antibody responses has been detected in many, but not all, natural hosts [19, 20, 24]. Whether this is related to the non-pathogenic outcome is unclear. 
Altogether, these studies show that there is no evidence of stronger anti-viral antibody and $\mathrm{T}$ cell responses in natural hosts as compared to HIV-1/SIVmac infections. They are either similar or weaker. Weaker responses might protect the host against immunopathological damage on the expense of a lack of virus replication control.

\section{Is the natural host of SIV able to restrict viral replication or does the virus target distinct cells or tissues?}

\section{Is the virus replicating less than in pathogenic HIV-1/SIVmac infections?}

There is no better control of viral replication than in HIV-1/SIVmac infections. The high mutation rate of SIVagm was the first indirect demonstration of an uncontrolled replication in vivo [27]. This has been confirmed in SMs that display plasma viremia levels similar to macaques during the chronic phase [28]. Subsequently, it has been shown in AGMs that plasma viremia can be very high during acute infection [19]. Similar to SIVmac infection in macaques, the peak of replication in natural hosts occurs between days 6 and 14 postinfection (p.i.), with plasma RNA copy numbers between $2 \times 10^{4}$ and $10^{9} / \mathrm{ml}$ [29]. The peak levels were independent of the initial blood $\mathrm{CD}^{+} \mathrm{T}$ cell counts [30, 31]. After this early peak in viral replication, there is a sharp decline of RNA copy levels to variable set-point levels [19]. Naturally infected AGMs and SMs display a considerably wide range of viral loads (VLs) with many animals displaying high viremia levels [32-34]. Similarly high plasma VLs are observed in mandrills and chimpanzees [18, 35, 36]. These high VLs might be important for an efficient spreading of the virus among the host population.

The lack of disease progression in the context of high VL led to the conclusion that a high viremia is not sufficient to induce AIDS (Tab.1). In humans also, high viremia is not always associated with disease progression. For example, a few HIV-1 infected long term non progressors (LTNP) have remained asymptomatic while presenting high viremia [37]. Recently, a case of a patient infected with HIV-1 for 20 years who has experienced CD $4^{+} \mathrm{T}$ cell depletion in spite of maintaining undetectable viral loads, has been described [38]. Moreover, HIV-2 infected individuals develop AIDS in the presence of low plasma VLs [39]. Aside from high viremia, additional factors must therefore play a role in the induction of immune dysfunction. 


\section{Is the virus replicating in distinct tissues?}

Differences in the outcome of the infection could be associated with a targeting to distinct tissues by the virus or by sparing specific organs such as thymus or intestine. The mucosal immune system plays a central role in both transmission of HIV infection and AIDS pathogenesis. The major site of HIV-1/SIVmac replication is indeed the gut. This is correlated with the fact that the gut associated lymphoid tissues (GALT) contain the most elevated frequency of activated $\mathrm{CD} 4^{+} \mathrm{T}$ cells and the highest number of viral target cells. Similar to SIVmac, however, SIVagm also replicates at high levels in the gut, both in the acute and the chronic phase of infection [40]. The infected cells are localized in the lamina propria and Peyer's patches [33, 41]. Moreover, the distribution of the virus in other tissues (e.g. thymus, cerebrospinal fluid, lungs...) is similar to HIV-1/SIVmac [32, 33, 40].

Only in LNs major differences have been reported between non-pathogenic and pathogenic HIV-1/SIVmac infections (Tab.2). While the number of productively infected cells in LNs during acute SIVagm infection is similar to SIVmac infection, this number is very low during the chronic phase (Tab.2) [9, 22, 42, 43]. Similar low numbers in LNs have also been reported for two SIVcpz-infected chimpanzees [43, 44]. For SMs, there is also no difference with SIVmac infection in the acute phase [4]. During the chronic phase, the numbers of RNA positive cells in the SM's LNs were equivalent to slow/ intermediate progressor macaques [28]. It is not excluded, that SMs show a slightly higher VL than AGMs in the chronic phase. So far, only 2 animals have been reported in the literature and more SMs need to be analyzed to answer to this question.

The proviral load in AGMs is also very low in LNs during the chronic phase of infection as compared to blood and gut $[19,32,42]$. This contrasts with humans infected with HIV-1 and macaques infected with SIVmac, which both show 5 to 10 times more extensive proviral burden in the LNs than in the peripheral blood mononuclear cells (PBMC) [45]. In line with the RNA and DNA loads, the average titer of infectious virus in AGM LNs is also low (21 $\mathrm{TCID}_{50}$ per $10^{6} \mathrm{LN}$ mononuclear cells) [42].

Productively infected cells in AGMs, SMs and chimpanzees are predominantly located in the T cell zone and little or no trapping of SIV by follicular dendritic cells is observed [28, 33, 42, 44]. The underlying mechanisms of this lack of virus trapping are not elucidated. It could be related to differences in the immune activation (IA) status in LNs of natural hosts (see below). The lack of virus trapping most likely results in higher levels of free virus particles in the blood. In that case, it would need less infected cells to achieve similar levels of viremia than 
in pathogenic HIV-1/SIVmac infections, which could explain the lower proviral burden in AGMs as compared to macaques.

Altogether, these data demonstrate similar VL levels between non-pathogenic SIV and pathogenic HIV-1/SIVmac infections in both blood and intestine. Nevertheless, a lower viral burden, at least for AGMs, is observed in the peripheral LNs in the chronic phase. The presence of less virus in the inductive sites of immune responses might have a beneficial impact, but this remains so far an open question that needs further investigation.

\section{Which cells are targeted?}

Some hypotheses put forward that the non-pathogenic outcome of SIVagm infection in AGMs is associated with a lower number of $\mathrm{CD}^{+} \mathrm{T}$ cells in this species. $\mathrm{CD} 4^{+} \mathrm{T}$ cell counts vary according to age and individuals. In young AGMs (1.4 to 3.5 years) the blood $\mathrm{CD}^{+} \mathrm{T}$ cell counts (between 800-2900, mean $1400 \mathrm{CD}^{+} \mathrm{T}$ cells/ $\mu \mathrm{l}$ ) are often not lower than in SMs and macaques, with a mean of $30 \%(<17-44 \%)$ of $\mathrm{CD}^{+} \mathrm{T}$ cells in PBMC. Adult AGMs (3.6-9.8 years old) have significantly reduced $\mathrm{CD}^{+} \mathrm{T}$ cell counts $\left(<250-1300\right.$, mean $\left.700 \mathrm{CD}^{+} / \mu \mathrm{l}\right)$ with $24 \%(<10-36 \%)$ of $\mathrm{CD}^{+} \mathrm{T}$ cells in PBMC [12, 31, 46]. Indeed, some adult AGMs display less than $300 \mathrm{CD}^{+} \mathrm{T}$ cells/ $\mu 1$ in blood [30, 31]. In humans, a lymphocyte count such as this would be associated with opportunistic infections and AIDS. Whether AGMs with low $\mathrm{CD}^{+} \mathrm{T}$ cell counts have been selected during evolution and whether this confers an advantage to the host during SIV infection is still an interesting matter of debate and needs further explorations.

Another interesting observation concerns the levels of $\mathrm{CD} 4^{+} \mathrm{CCR} 5^{+} \mathrm{T}$ cells in natural hosts. These levels are significantly lower than in humans and non natural hosts for SIV, both in blood and tissues [47]. The frequency of $\mathrm{CCR}^{+}$plasmacytoid DCs (pDC) is also lower [48]. Like SIVmac, SIV from African NHPs use CCR5 as a major coreceptor [49-51]. There are however few exceptions (Tab.3). For instance, SIVrcm uses CCR2b instead of CCR5. The latter is characterized by a $24 \mathrm{bp}$ deletion in red capped mangabeys [50]. SIV viruses most of the time are not CXCR4 tropic. However, some primary SIVagm and SIVsm isolates are able to use CXCR4 in addition to CCR5 for cell entry [30,52-54]. The ability of SIVs to replicate in human $\mathrm{T}$ cell lines without using CXCR4 has suggested the existence of additional simian co-receptors. Bonzo/STLR33 is preferentially used by SIVagm [51] and Bob by SIVsm/SIVmac in vitro [55]. Still, CCR5 is the major co-receptor for SIVsm and SIVagm in vitro and in vivo [50, 51]. A frequent mutation found in CCR5 of AGMs results in a molecule that is still functional for SIVagm but not for HIV-1. This is a sign that SIVagm is adapted 
specifically to CCR5 of AGMs. Altogether, SIVs from natural hosts show a similar coreceptor usage to SIVmac.

It is a paradox that SIVsm and SIVagm, which use CCR5 as a major coreceptor, induce high VLs in the context of these low levels of $\mathrm{CD}^{+} \mathrm{CCR}^{+} \mathrm{T}$ cells. Thus, the levels of CCR5 expression may still be sufficient to allow infection in vivo. In line with this, in macaques' intestine, the majority of infected cells have a CCR5 $5^{-}$phenotype [56]. The meaning of the lower frequencies of $\mathrm{CCR}^{+}$cells in the protection against pathogenesis needs to be clarified. It could play a role in distinct cell trafficking or be related to a distinct differentiation stage of target cells in natural hosts. It has been hypothesized that in natural SIV hosts, expression of CCR5 is restricted to $\mathrm{CD} 4^{+} \mathrm{T}$ cells that are in a more advanced differentiation stage, thereby limiting virus replication to a subset of $\mathrm{CD} 4^{+} \mathrm{T}$ cells that are anyway destined for activation induced cell death regardless of their SIV infection status [57]. In line with this, the bulk of SIVagm replication is sustained by very short lived cells, as suggested by mathematical modeling [58]. The exact phenotype of infected $\mathrm{CD}^{+} \mathrm{T}$ cells has not been explored so far. It is known however that, in vivo, most productively infected $\mathrm{CD} 4^{+} \mathrm{T}$ cells in the gut display a memory phenotype [41]. They rarely express Ki67 at the peak [41, 59]. SIVagm also replicates in antigen-presenting cells, such as macrophages (Fig.1) [33]. No data are yet available on the susceptibility of dendritic dells (DC) from African NHP to SIV infection. AGM Monocyte DC efficiently transmit SIVagm to T cells through DC-SIGN in vitro [60]. The lower VL in AGM LN is thus not related to a lack of DC-T cell transmission.

In the state of knowledge, except of the levels of $\mathrm{CD} 4^{+} \mathrm{CCR} 5^{+} \mathrm{T}$ cells that differ between natural hosts and macaques, there are no major differences reported between non-pathogenic and pathogenic infection regarding the target cells. However the nature of the infected CD4 ${ }^{+}$ cell subpopulations $\left(\mathrm{CD}^{+} \mathrm{T}\right.$ cells and $\left.\mathrm{DCs}\right)$ in natural hosts is only poorly defined. More studies on the phenotype of the infected cells are urgently needed. Moreover, it is important to understand why viral replication in LNs during the chronic phase is lower in non-pathogenic SIVagm infection. It could be a consequence of less target cells. Like HIV/SIVmac, SIV isolates from natural hosts replicate preferentially in $\mathrm{CD}^{+} \mathrm{T}$ cells when they are in an activated state and generally do not grow in unstimulated PBMCs in vitro [61-63]. The level of viral replication in vivo correlates with the frequency of activated $\mathrm{T} \mathrm{CD} 4^{+}$cells in naturally infected SMs [64]. It is likely that the availability of activated $\mathrm{T} \mathrm{CD} 4^{+}$cells rather than immune control of viral replication is the main determinant of set-point VL during SIV infection in natural hosts [64]. Thus, the lower level of viral replication in LNs could be 
related to a lower level of chronically activated $\mathrm{CD}^{+} \mathrm{T}$ cells as compared to the gut in nonpathogenic SIV infection.

\section{Does the virus cause less immunological damage in the natural hosts?}

\section{Early depletions of peripheral CD4 ${ }^{+} \mathrm{T}$ Cells}

In humans and macaques, sustained high VL is most often associated with $\mathrm{CD}^{+} \mathrm{T}$ cell declines. In contrast, chronic SIV infections of African NHPs are generally characterized by preservation of healthy blood $\mathrm{CD} 4^{+} \mathrm{T}$ cell counts despite high levels of viremia. It is of note that in acute infection, AGMs, SMs and mandrills demonstrate a significant drop in peripheral $\mathrm{CD}^{+} \mathrm{T}$ cell counts (Tab.1) $[18,30,65,66]$. This drop is more pronounced in the animals that show a higher $\mathrm{CD}^{+} \mathrm{T}$ cell count at day 0 [30]. It is preferentially observed in AGMs displaying high peak viremia. At the end of the acute infection, the $\mathrm{CD} 4^{+} \mathrm{T}$ cell values in the blood rebound rapidly to set-point values that are often lower although still close to healthy levels $[41,66]$. In the chronic phase, SIV infection in SMs is associated sometimes, but not always, with a moderate decline in $\mathrm{CD}^{+} \mathrm{T}$ cells [67]. Although SIV infection can thus have a moderate impact on $\mathrm{CD} 4^{+} \mathrm{T}$ cell counts, the latter remain generally close to normal levels in blood.

A transient decrease in $\mathrm{CD}^{+}{ }^{+} \mathrm{T}$ cells has been occasionally observed in the LNs of AGMs and mandrills during acute infection, however not in all monkeys that display a depletion in the blood [18, 41, 65]. Again, the normal levels are readily recovered by the end of the acute phase.

\section{Depletion of Mucosal CD4 ${ }^{+}$T Cells}

In the GALT, the early kinetics of $\mathrm{CD}^{+} \mathrm{T}$ cell depletion are also the same than for pathogenic infections (Tab.1). Thus, an early dramatic depletion of mucosal $\mathrm{CD}^{+} \mathrm{T}$ cells is observed in SMs and AGMs [41, 68]. A rapid drastic depletion of GALT-based memory $\mathrm{CD} 4^{+} \mathrm{CCR} 5^{+} \mathrm{T}$ cells is a characteristic feature in HIV-1-infected individuals and SIV-infected rhesus macaques $[69,70]$. The cell population that was the most affected in natural hosts corresponds also to memory cells, being defined as $\mathrm{CD}^{+} \mathrm{CD} 4^{+} \mathrm{CD} 28^{+} \mathrm{CD} 95^{+}$cells $[41,68]$. 
However, while disease progression in macaques is associated with a further decline in mucosal $\mathrm{CD}^{+} \mathrm{T}$ cells in the chronic phase of infection, this was not the case in SMs, at least until day 175 p.i. [68]. AGMs even recovered partially their $\mathrm{CD}^{+}$cells in gut, the levels being $35-75 \%$ of baseline by day 410 p.i. [41]. A better recovery of $\mathrm{CD}^{+} \mathrm{T}$ cells in AGMs as compared to SMs might be related to their lower VL in the chronic phase of infection as shown in LNs (Tab.2) and blood. Set-point values of plasma VL are indeed 1 log lower for AGMs than SMs, mandrills and chimpanzees for the other species [29]. To test this hypothesis, comparative quantitative analysis of VL in the intestine of these two species needs to be done.

It is intriguing that the peripheral $\mathrm{CD}^{+} \mathrm{T}$ cell counts in natural hosts are preserved despite their dramatic loss in the gut. IL-7 is known for playing an important role in homeostatic proliferation of $\mathrm{CD}^{+}$memory $\mathrm{T}$ cells and IL-7 levels are often elevated in T cell-depleting conditions. During acute SIV infection SMs, IL-7 increases are observed in temporal association with the early declines in peripheral CD4+ T cell counts. This early transient IL-7 increase is followed by increases in $\mathrm{CD}^{+}$and $\mathrm{CD}^{+} \mathrm{T}$ cell proliferation [66]. Interestingly, the natural hosts, whether infected or not, display signs of higher $\mathrm{T}$ cell proliferation in bone marrow and an inherently high rate of peripheral $\mathrm{CD} 4^{+} \mathrm{T}$ cell turnover, raising the question as to whether there is a better compensation for loss of infected cells in natural hosts [71, 72]. Moreover, while bystander cell death of $\mathrm{CD}^{+} \mathrm{T}$ cells has been demonstrated in natural hosts (chimpanzees, AGMs, SMs), the latter display no increased apoptosis of $\mathrm{CD}^{+} \mathrm{T}$ cells in blood [71, 73]. In AGMs, there is also no increase of apoptosis in LN and gut during acute or chronic infection [22, 41]. In SMs, there is an increase at day 14 p.i. in LN followed by a rapid return to normal levels [4]. There is therefore no chronically increased CD4 ${ }^{+} \mathrm{T}$ cell apoptosis in natural hosts. It is thus probably easier to maintain homeostasis, since there is no need to compensate a loss of non-infected $\mathrm{CD} 4^{+} \mathrm{T}$ cells dying by bystander cell death. In addition, the nature of the depleted cells might not be the same in pathogenic and nonpathogenic HIV/SIV infections. For instance, SIVmac infection results in depletion of Th17 cells in GALT of macaques, whereas in AGMs and SMs, the Th17 cells are preserved [74] [Cervasi et al., 2008 ${ }^{1}$, Favre et al., $2008^{2}$ ]

\footnotetext{
${ }^{1}$ B. Cervasi, J. Brenchley, M. Paiardini, S. Gordon, A. Asher, I. Frank, J. Else, D. Douek, and G. Silvestri. Preferential Loss of Th17 CD4 T Cells in the Gastrointestinal Tract of HIV-infected Individuals but Not SIVinfected Sooty Mangabeys. February 3-6, 2008. Conference on Retroviruses and Opportunistic Infections, Boston, Massachusetts.

${ }^{2}$ D. Favre, S. Lederer, B. Kanwar, Z. M. Ma, S. Proll, Z. Kasakow, C. Miller, M. Katze, and J. McCune. Primary SIV Infection Causes Rapid Loss of the Balance between TH17 and T Regulatory Cell Populations in
} 
Natural hosts are therefore characterized by early significant $\mathrm{CD} 4^{+} \mathrm{T}$ cell declines in acute infection that persist in the chronic phase in intestine of SMs. Moreover, very low peripheral $\mathrm{CD}^{+} \mathrm{T}$ cell counts without any sign of AIDS can be occasionally observed in AGMs and SMs $[31,33,75]$. Studies in natural hosts therefore indicate that losses of CD4 ${ }^{+} \mathrm{T}$ cells are necessary but not sufficient to cause AIDS. Aside from high viremia and early $\mathrm{CD}^{+} \mathrm{T}$ cell losses, additional processes are necessary. In macaques, it is not the degree of early $\mathrm{CD}^{+} \mathrm{T}$ cell decline in mucosa, but rather the degree of recovery in the post-acute and early chronic phase that are correlated with the outcome of infection [76, 77]. During antiretroviral therapy, $\mathrm{CD}^{+} \mathrm{T}$ cell restoration in GALT is best achieved when inflammation is suppressed [78]. It is crucial to understand why in AGMs and SMs, the $\mathrm{CD}^{+} \mathrm{T}$ cells in gut do not further decline in contrast to macaques that progress towards AIDS.

\section{Lack of chronic T cell activation}

The most striking difference between non-pathogenic SIV and pathogenic HIV-1/SIVmac infections is the lack of chronic $\mathrm{T}$ cell activation in the natural hosts despite the ongoing viral replication (Tab.1). In HIV-1/SIVmac infections, high viremia correlates with IA. IA seems to be a better prediction factor for disease progression than VL [39, 79-82]. Already before seroconversion, $\mathrm{CD}^{+} \mathrm{T}$ cell activation levels in HIV-1 infection are predictive of the rate at which $\mathrm{CD}^{+} \mathrm{T}$ cells are lost over time [11]. In natural hosts (AGMs, SMs), increases of $\mathrm{T}$ cell activation measured by markers such as Ki67 and MHC-II can be observed during acute infection in the blood, especially in animals displaying high viremia at the peak [4, 65]. However, the increase is only transient and there is a rapid and substantial resolution of $\mathrm{T}$ cell activation. As a result, during the chronic phase, the levels are close to baseline levels $[65,67$, $71,83]$. There is nevertheless a marked inter-individual variability with respect to $\mathrm{CD} 8^{+} \mathrm{T}$ cell activation levels and some SMs display non-significant increases. The moderate decreases in $\mathrm{CD} 4^{+} \mathrm{T}$ cell counts in SMs are observed in those animals with higher $\mathrm{CD} 8^{+} \mathrm{T}$ cell activation [71]. Thus even in natural hosts, SIV infection impacts the immune system, but only to a weak extend without leading to generalized IA and impaired homeostasis.

In LNs, signs of transient $\mathrm{T}$ cell activation are also observed during acute infection [4, 22]. However, the levels of $\mathrm{CD}^{+}$and $\mathrm{CD}^{+} \mathrm{T}$ cell proliferation are not substantially increased during the chronic phase $[22,71]$. In line with this, natural hosts do not exhibit LN follicular or paracortical hyperplasia, nor infiltrations of $\mathrm{CD}^{+} \mathrm{T}$ cells into LN germinal centers [19,

Pathogenic Infection of Non-human Primates. February 3-6, 2008. Conference on Retroviruses and Opportunistic Infections, Boston, Massachusetts. 
33]. There is no evidence of increased collagen deposition in post-acute and chronic phase of infection resulting in no tissue damage through fibrosis [4]. Tissular architecture in LNs is indeed conserved [19, 42].

In the gut, the IA seems to be lower in natural hosts as well. Thus, the levels of plasma lipopolysaccharide (LPS) were increased in a few SIV-infected African NHPs during acute infection, but not in all of them, and never during chronic infection, by opposition to HIV1/SIVmac infections [41, 68, 84]. Plasma LPS is a marker of IA and is the result of translocation of microbial products to the systemic circulation [84]. The mechanisms underlying the disruption of the mucosal barrier in HIV-infected individuals and SIVmacinfected rhesus macaques are not clear. Th17 cells play a role in the protection against microbial infections $[85,86]$. Consequently, depletion of Th17 cells during HIV-1/SIVmac infection contributes to dissemination of pathogenic bacteria [87]. Other mechanisms could play a role as well in the disruption of the mucosal barrier in HIV-1/SIVmac infections. Thus, the early SIVmac infection phase is associated with a massive apoptosis of intestinal epithelial cells that might represent the underlying mechanism of the regenerative enteropathy [88]. Interestingly, no apoptosis was observed in the gut of acutely infected SIVagm-infected AGMs [41]. The reasons why natural hosts display lower levels of apoptosis and whether this is simply the consequence of lower IA or due to other factors, still needs to be established.

Despite high levels of VLs, natural hosts therefore show a rapid control of $\mathrm{T}$ cell activation and normal or only moderate IA during chronic infection compared to humans and macaques. The studies in natural hosts have contributed to the present point of view that IA is the driving force for $\mathrm{CD}^{+} \mathrm{T}$ cell depletion and AIDS, while viral replication is only indirectly associated with disease progression, probably through increasing IA. To understand how HIV-1/SIVmac induce chronic IA and how natural hosts protect themselves against it, presents a major and the most important challenge today.

\section{Potential mechanisms of immune activation control}

Several studies are currently in progress to determine which factors are involved in the maintenance of the low activation level in the non-pathogenic models. Two ways of achieving it are possible: (i) a lack of IA induction and/or (ii) an active downregulation of it (Fig.2).

\section{Less induction of activation?}

The first sentinels that sense signals of infection are the cells of the innate immune system. Microbes and viruses are sensed through pattern-recognition receptors (PRR), such as Toll 
like receptors (TLR). These receptors bind pathogen-associated-molecular-pattern molecules (PAMP) [89]. PAMPs induce the secretion of pro-inflammatory cytokines including TNF- $\alpha$, IL-6, IL-12 and type I interferon (IFN-I) by binding to TLRs. IFN-I is induced through TLR3, 7, 8 and 9. TLR3 recognizes double-stranded viral RNA and is expressed on myeloid DCs (mDCs) [90, 91]. TLR7 and 8 recognize single-stranded viral RNA [92, 93], and TLR9 is stimulated by unmethylated DNA rich in cytosine-guanosine motifs from bacteria and viruses [94]. TLR7 and 9 are expressed on pDCs and TLR8 on monocytes and mDCs [91, 95]. HIV-1 signals directly through TLR7 which results in the production of TNF- $\alpha$ and IFN- $\alpha$ [96]. A signaling by HIV-1 through TLR9 is not excluded [93, 96].

The considerable inter-individual variation in humans and macaques regarding IA levels might be related in part to individual differences at the level of TLR expressions or functions. The expression of some TLRs is altered during HIV-1/SIVmac infections. TLR7 and 8 mRNA levels were significantly increased in subjects with chronic HIV-1 infection and that of TLR3, TLR7 and TLR8 in LNs of SIV-infected macaques [97-99]. On the other hand, TLR9 expression is decreased in LNs in the early phase of SIVmac infection and HIV-1 GP120 seems to diminish TLR9 signaling [98, 100, 101]. During HIV/SIVmac infections, pro-inflammatory cytokines might also be induced indirectly by exposing innate immune cells to co-infecting agents [102]. For instance, as a result of bacterial translocation, PAMPs, such as the TLR4 ligand LPS, could be involved in further driving general IA [84]. Still, there is not enough data so far to directly link differences at the level of TLR expressions and/or stimulations with IA levels.

We explored the inflammatory cytokine profiles in non pathogenic SIV infection. We measured cytokine expressions in three distinct body compartments: blood, LNs (induction site) and bronchioalveolar lavages (mucosa associated lymphoid tissue, effector site) of acutely SIVagm-infected AGMs (Tab.4). Strikingly, AGMs displayed only weak increases of IFN- $\gamma$, and no significant increases of TNF- $\alpha$, IL- 6 , IL-12, MIP- $1 \alpha$ and MIP-1 $\beta$ during acute infection $[65,103]$. To confirm this weak inflammatory profile in SIVagm infection, we have quantified the expression of $t$-bet and gata3 in acute infection. These transcription factors are essential for the induction of Th1 and Th2 responses, respectively. In the PBMCs of both AGMs and macaques, gata3 expression was upregulated [104]. However, only macaques presented an upregulation of $t$-bet, whereas AGMs did not. This is in agreement to the weak induction of pro-inflammatory cytokines. In conclusion, SIVagm-infection in AGMs is characterized by a lack of inflammatory responses resulting in a Th2/anti-inflammatory 
cytokine balance. A tendency towards Th2 cells has also been reported in chronically infected SMs [71, 105], although SIV-specific $\mathrm{CD}^{+} \mathrm{T}$ cell preferentially secrete Th1 cytokines [13]. A lack in early inflammatory cytokine production is likely to play an essential role in the low T cell activation profiles (Fig. 2).

Little is known about TLR expression and signaling in the non-pathogenic models. There might be an intrinsic lower response to SIV in African NHPs. Indeed, stimulation of TLR9 from pDCs of uninfected AGMs results in IFN- $\alpha$ production at levels significantly lower than those in healthy human donors and macaques [103, 106]. Nonetheless, under certain circumstances, TLR9 stimulation on AGM pDCs results in high IFN- $\alpha$ production. This is the case during acute SIVagm infection, where pDCs from blood and LNs display strong IFN- $\alpha$ production after ex vivo stimulation with a TLR9 ligand [103]. IFN- $\alpha$ levels in plasma are indeed increased during acute SIVagm infection. The levels were positively correlated with plasma VL [103]. However, plasma IFN- $\alpha$ was only detectable around the peak of viremia and the absolute levels were significantly lower than in SIVmac infection [103]. In chronic HIV-1/SIVmac infection plasma IFN- $\alpha$ levels and ISG expressions increase with progression towards AIDS. IFN- $\alpha$ does not seem to play an important role in HIV/SIV replication containment, and chronic production might even be deleterious for the immune system [107, 108]. Thus little or no chronic IFN- $\alpha$ production could be of benefit by inducing less immunopathological damage.

Studies in SMs also show substantially reduced levels of innate immune system activation [48]. Thus, in vitro stimulated pDC from non infected SMs produce markedly less IFN- $\alpha$ than macaque pDC. However, after stimulation with inactivated SIV or a TLR9 agonist, a similar production of TNF- $\alpha$ and IL-12 could be observed for SMs and macaques, suggesting that while the pathway that requires IRF7 is compromised, the NFKB-dependent signaling pathway is intact in SM's pDC [48]. In vivo, the expression of inflammatory cyokines such as TNF- $\alpha$, IL-6 and IL-12 mRNAs was significantly lower in chronically infected SMs than in macaques [48]. The reasons why natural hosts display a lack of pro-inflammatory cytokine production in response to SIV infection seem to be complex and far from being completely understood.

\section{Rapid induction of immunosuppressive mechanisms?}

HIV-1/SIVmac infections are associated with increases in immunosuppressive mediators, such as that of regulatory $\mathrm{T}$ cells (Treg) in tissues, or of TGF- $\beta 1^{+}, \mathrm{IDO}^{+}$and PD- $1^{+}$cells in 
blood or LNs [109-112]. This is most likely a response by the host to try to control inflammation and immune-mediated pathological damage. However, these responses do not appear to be capable of limiting the massive hyperactivation [109].

Treg play a central role in controlling deleterious immune responses such as inflammation [113]. They also facilitate early protective responses to local viral infection by allowing a timely entry of immune cells into infected tissues [114]. The timing of their induction and their localization in HIV/SIV infections might be a critical determinant for the outcome of infection. Treg represent a heterogeneous fraction of $\mathrm{T}$ cells that include IL-10 secreting $\operatorname{Tr} 1$ cells, TGF- $\beta 1$ producing Th3 cells, as well as naturally CD $25^{+}$Treg and adaptive IL-10 and TGF- $\beta 1$ secreting CD $25^{+}$Treg. CD $25^{+}$Treg have been detected in HIV/SIVmac infection, but their implication is not clear and contradictory data have been published. In some studies, $\mathrm{CD} 25^{+}$Treg seem to be correlated with a lower VL, a diminished IA and a slower progression towards AIDS; while in others, they are associated with suppression of virus-specific immune responses and disease progression [109, 113, 115].

In SIVagm-infected AGMs, some animals showed early increases of IL-10, TGF- $\beta 1$ and FoxP3 expression [65]. TGF- $\beta 1$ is able to induce $\mathrm{CD} 25^{+}$FoxP3 $3^{+}$Treg in vivo. On the other hand, IL-6, which is increased in macaques but not in AGMs, can prevent CD $4^{+} \mathrm{CD} 25^{+}$Treg functions [116]. It is thus possible that, due to the particular cytokine environment during early SIVagm infection, DCs are conditioned to preferentially induce regulatory $\mathrm{T}$ cells rather than Th1 cells. However, it has yet to be demonstrated if the FoxP3 ${ }^{+}$cells detected in AGMs correspond to Treg cells, since FoxP3 and CD25 are also upregulated upon activation [117]. One could nonetheless hypothesize that a more rapid immunosuppressive response in AGMs could abrogate immune hyperactivation, resulting in a far more benign disease outcome in comparison to that in macaques. The Treg cell response in SIV-infected macaques may be too late to counterbalance and prevent the immunopathological consequences of sustained IA, and too early and untimely with respect to immune control, as it down-regulates important effector T cell responses before immune control is achieved [65, 109]. In AGMs, the Treg cell response would also inhibit antigen-specific $\mathrm{T}$ cell responses, resulting in viral replication levels comparable to those in SIV-infected macaques, but they would be early enough to prevent the immunopathological effects of sustained IA.

$\mathrm{CD} 25^{+}$Treg have also been described in SIVsm infection in SMs [118, 119]. It is not excluded that their suppressive function is more pronounced in SMs as compared to macaques 
[118]. There has been, however, no correlation detected so far between Treg levels and IA resolution $[4,118,119]$.

In SMs, the resolution of early $\mathrm{T}$ cell activation in LNs was rather associated with a more rapid increase in PD-1 expression compared to macaques [4]. Whether this is related to differences among the natural host species, to the lack of specific Treg markers or to the lack of studies of PD-1 in acute SIVagm infection, must be further investigated. PD-1 is known to be associated with suppression of $\mathrm{T}$ cell responses [120, 121]. The rapid increase in PD-1 expression in SMs was observed particularly in the $\mathrm{CD}^{-}\left(\mathrm{CD}^{+}\right) \mathrm{T}$ cell fraction. It paralleled the decreases in $\mathrm{T}$ cell proliferation and effector functions. Notably, there was a strong positive temporal association of PD-1 levels with IA resolution in LNs of SMs, whereas the increase in the level of IA over time was not affected by the level of PD-1 expression in macaques.

The expression of PD- 1 is enhanced by TGF- $\beta 1$ in vitro [110]. It is not excluded that TGF- $\beta 1$ induction during the first days p.i. is stronger in natural hosts [65]. It could also be that in pathogenic HIV/SIVmac infections there is a diminished sensitivity to TGF- $\beta 1$ signaling in $\mathrm{T}$ cells. The TGF- $\beta 1$ major pathway is mediated by the Smad proteins. Smad3 and 4 are activators of the pathway, whereas Smad7 is one inhibitor of this pathway. We quantified smad7 mRNA levels and detected an up-regulation of smad7 transcripts in PBMC of acutely SIV-infected macaques. In contrast, the AGMs were characterized by a longer lasting upregulation of smad4 with no or a less detectable increase in smad7 expression [104]. These results are in favor of the hypothesis of a reduced responsiveness to TGF- $\beta 1$ during primary SIVmac infection, which could result in a delay of TGF- $\beta 1$ dependent Treg and PD-1 induction and/or of $\mathrm{T}$ cell proliferation inhibition.

Collectively, these data support the hypothesis of a more rapid induction of immunosuppressive mediators in non-pathogenic SIV infection contributing to the rapid resolution of acute IA. Several mechanisms have been proposed for IA control in natural host. They all relate to a very early control of inflammation. They are not mutually exclusive and might even partially depend on each other. Further investigations are required to evaluate the impact of each of them on IA and AIDS protection.

\section{Conclusion}


In conclusion, non-pathogenic SIV infections are characterized by a delicate balance between high viral replication and a moderate host immune response. Natural hosts of SIV thus resemble those few LTNPs who maintain their $\mathrm{CD}^{+} \mathrm{T}$ cell counts despite high viremia levels [37]. Both have in common a very weak or absent chronic T cell activation (Fig.2). Current efforts are employed to understand the underlying mechanisms. Recent data in NHPs point toward important differences at the level of the innate immune system and the timing of induction of immunosuppressive mediators during acute infection.

In the future, more studies are needed to identify the responsible key elements in the regulation of $\mathrm{T}$ cell activation in the natural hosts. In particular, more detailed analysis on the phenotype of the infected $\mathrm{CD}^{+}{ }^{\mathrm{T}}$ cells, their localization and numbers in the intestine, and the role of the low numbers in LNs in the preservation of the host immune system will be of importance. In parallel, more studies are needed to examine the role of the mediators of the innate immune system in the weak inflammatory responses. These could be antigenpresenting cells, in particular pDC, but also, NK cells, $\gamma \delta \mathrm{T}$ cells and neutrophils. Moreover, non immune cells such as epithelial cells, might play a role in the early cytokine profiles. Finally, phenotypical and functional studies of cells expressing molecules associated with immunosuppression (FoxP3, IDO, PD-1) should be further developed.

These studies will be crucial to delineate the mechanistic basis for the IA control during SIV infection in natural host species. They pave the way for a series of in vivo experiments that that target the early inflammatory pathways. On the long term, this could contribute to the development of new prophylactic and therapeutic strategies that aim to protect against AIDS.

\section{ACKNOWLEDGEMENTS}

Our studies were supported by the French Agency for AIDS Research (ANRS), Sidaction and Institut Pasteur. Anne-Sophie Liovat was a recipient of a scholarship from the French "Ministère de l'Enseignement Supérieur et de la Recherche" and from the Denis Diderot University (Paris 7). We thank Matthew Marx for reviewing the English as well as Désirée Kunkel and Asier Saez-Cirion for helpful discussions.

\section{References}


1. Hahn BH, Shaw GM, De Cock KM, Sharp PM. AIDS as a zoonosis: scientific and public health implications. Science 2000;287(5453):607-14.

2. Van Heuverswyn F, Li Y, Neel C, et al. Human immunodeficiency viruses: SIV infection in wild gorillas. Nature 2006;444(7116):164.

3. Keele BF, Van Heuverswyn F, Li Y, et al. Chimpanzee reservoirs of pandemic and nonpandemic HIV-1. Science 2006;313(5786):523-6.

4. Estes JD, Gordon SN, Zeng M, et al. Early resolution of acute immune activation and induction of PD-1 in SIV-infected sooty mangabeys distinguishes nonpathogenic from pathogenic infection in rhesus macaques. J Immunol 2008;180(10):6798-807.

5. Fultz PN, McClure HM, Anderson DC, Switzer WM. Identification and biologic characterization of an acutely lethal variant of simian immunodeficiency virus from sooty mangabeys (SIV/SMM). AIDS Res Hum Retroviruses 1989;5(4):397-409.

6. Wain LV, Bailes E, Bibollet-Ruche F, et al. Adaptation of HIV-1 to its human host. Mol Biol Evol 2007;24(8):1853-60.

7. Beer BE, Brown CR, Whitted S, et al. Immunodeficiency in the absence of high viral load in pig-tailed macaques infected with Simian immunodeficiency virus SIVsun or SIVlhoest. J Virol 2005;79(22):14044-56.

8. Hirsch V, Dapolito G, Johnson PR, et al. Induction of AIDS by simian immunodeficiency virus from an African green monkey: species-specific variation in pathogenicity correlates with the extent of in vivo replication. J. Virol. 1995;69:955967.

9. Goldstein S, Ourmanov I, Brown CR, et al. Plateau levels of viremia correlate with the degree of CD4+-T-cell loss in simian immunodeficiency virus SIVagm-infected pigtailed macaques: variable pathogenicity of natural SIVagm isolates. J Virol 2005;79(8):5153-62.

10. Mellors JW, Kingsley LA, Rinaldo Jr. CR, et al. Quantitation of HIV-1 RNA in plasma predicts outcome after seroconversion. Ann.Int.Med. 1995;122:573-579.

11. Deeks SG, C. M. Kitchen, L. Liu, H. Guo, R. Gascon, A. B. Narvaez, P. Hunt, J. N. Martin, J. O. Kahn, J. Levy, M. S. McGrath, and F. M. Hecht. . Immune activation set point during early HIV infection predicts subsequent CD4+ T-cell changes independent of viral load. Blood 104:942-7. 2004.

12. Buijs L, Bogers WM, Eichberg JW, Heeney JL. CD8+ cell-mediated immune responses: relation to disease resistance and susceptibility in lentivirus-infected primates. J Med Primatol 1997;26(3):129-38.

13. Wang Z, Metcalf B, Ribeiro RM, McClure H, Kaur A. Th-1-type cytotoxic CD8+ Tlymphocyte responses to simian immunodeficiency virus (SIV) are a consistent feature of natural SIV infection in sooty mangabeys. J Virol 2006;80(6):2771-83.

14. Dunham R, Pagliardini P, Gordon S, et al. The AIDS resistance of naturally SIVinfected sooty mangabeys is independent of cellular immunity to the virus. Blood 2006;108(1):209-17.

15. Kaur A, Alexander L, Staprans SI, et al. Emergence of cytotoxic T lymphocyte escape mutations in nonpathogenic simian immunodeficiency virus infection. Eur J Immunol 2001;31(11):3207-17.

16. Zahn RC, Rett MD, Korioth-Schmitz B, et al. Simian Immunodeficiency Virus (SIV)specific CD8+ $\mathrm{T}$ cell responses in chronically SIVagm-infected vervet African green monkeys. J Virol 2008.

17. Barry AP, Silvestri G, Safrit JT, et al. Depletion of CD8+ cells in sooty mangabey monkeys naturally infected with simian immunodeficiency virus reveals limited role for immune control of virus replication in a natural host species. J Immunol 2007;178(12):8002-12. 
18. Onanga R, Kornfeld C, Pandrea I, et al. High levels of viral replication contrast with only transient changes in CD4(+) and CD8(+) cell numbers during the early phase of experimental infection with simian immunodeficiency virus SIVmnd-1 in Mandrillus sphinx. J Virol 2002;76(20):10256-63.

19. Diop OM, Gueye A, Dias-Tavares M, et al. High levels of viral replication during primary simian immunodeficiency virus SIVagm infection are rapidly and strongly controlled in African green monkeys. J Virol 2000;74(16):7538-47.

20. Fultz PN, Stricker RB, McClure HM, et al. Humoral response to SIV/SMM infection in macaque and mangabey monkeys. J Acquir Immune Defic Syndr 1990;3(4):319-29.

21. Chakrabarti LA. The paradox of simian immunodeficiency virus infection in sooty mangabeys: active viral replication without disease progression. Front Biosci 2004;9:521-39.

22. Cumont MC, Diop O, Vaslin B, et al. Early divergence in lymphoid tissue apoptosis between pathogenic and nonpathogenic simian immunodeficiency virus infections of nonhuman primates. J Virol 2008;82(3):1175-84.

23. Chakrabarti L, Baptiste V, Khatissian E, et al. Limited viral spread and rapid immune response in lymph nodes of macaques inoculated with attenuated simian immunodeficiency virus. Virology 1995;213:535-548.

24. Norley SG, Kraus G, Ennen J, et al. Immunological studies of the basis for the apathogenicity of simian immunodeficiency virus from African green monkeys. Proc Natl Acad Sci U S A 1990;87(22):9067-71.

25. Kaur A, Grant RM, Means RE, et al. Diverse host responses and outcomes following simian immunodeficiency virus SIVmac239 infection in sooty mangabeys and rhesus macaques. J Virol 1998;72(12):9597-611.

26. Gicheru MM, Otsyula M, Spearman P, et al. Neutralizing antibody responses in Africa green monkeys naturally infected with simian immunodeficiency virus (SIVagm). J Med Primatol 1999;28(3):97-104.

27. Muller-Trutwin MC, Corbet S, Tavares MD, et al. The evolutionary rate of nonpathogenic simian immunodeficiency virus (SIVagm) is in agreement with a rapid and continuous replication in vivo. Virology 1996;223(1):89-102.

28. Rey-Cuille MA, Berthier JL, Bomsel-Demontoy MC, et al. Simian immunodeficiency virus replicates to high levels in sooty mangabeys without inducing disease. J Virol 1998;72(5):3872-86.

29. Pandrea I, Silvestri G, Onanga R, et al. Simian immunodeficiency viruses replication dynamics in African non-human primate hosts: common patterns and species-specific differences. J Med Primatol 2006;35(4-5):194-201.

30. Pandrea I, Kornfeld C, Ploquin MJ, et al. Impact of viral factors on very early in vivo replication profiles in simian immunodeficiency virus SIVagm-infected African green monkeys. J Virol 2005;79(10):6249-59.

31. Beer B, Denner J, Brown CR, et al. Simian immunodeficiency virus of African green monkeys is apathogenic in the newborn natural host. J Acquir Immune Defic Syndr Hum Retrovirol 1998;18(3):210-20.

32. Broussard SR, Staprans SI, White R, et al. Simian immunodeficiency virus replicates to high levels in naturally infected African green monkeys without inducing immunologic or neurologic disease. J Virol 2001;75(5):2262-75.

33. Goldstein S, Ourmanov I, Brown CR, et al. Wide range of viral load in healthy african green monkeys naturally infected with simian immunodeficiency virus. J Virol 2000;74(24):11744-53. 
34. Apetrei C, Gautam R, Sumpter B, et al. Virus subtype-specific features of natural simian immunodeficiency virus SIVsmm infection in sooty mangabeys. J Virol 2007;81(15):7913-23.

35. Ling B, Santiago ML, Meleth S, et al. Noninvasive detection of new simian immunodeficiency virus lineages in captive sooty mangabeys: ability to amplify virion RNA from fecal samples correlates with viral load in plasma. J Virol 2003;77(3):2214-26.

36. ten Haaft P, Murthy K, Salas M, et al. Differences in early virus loads with different phenotypic variants of HIV-1 and SIV(cpz) in chimpanzees. Aids 2001;15(16):208592.

37. Choudhary SK, Vrisekoop N, Jansen CA, et al. Low immune activation despite high levels of pathogenic human immunodeficiency virus type 1 results in long-term asymptomatic disease. J Virol 2007;81(16):8838-42.

38. Andrade A, Bailey JR, Xu J, et al. CD4+ T cell depletion in an untreated HIV type 1infected human leukocyte antigen-B*5801-positive patient with an undetectable viral load. Clin Infect Dis 2008;46(8):e78-82.

39. Sousa AE, Carneiro J, Meier-Schellersheim M, Grossman Z, Victorino RM. CD4 T cell depletion is linked directly to immune activation in the pathogenesis of HIV-1 and HIV-2 but only indirectly to the viral load. J Immunol 2002;169(6):3400-6.

40. Gueye A, Diop OM, Ploquin MJ, et al. Viral load in tissues during the early and chronic phase of non-pathogenic SIVagm infection. J Med Primatol 2004;33(2):83-97.

41. Pandrea IV, Gautam R, Ribeiro RM, et al. Acute loss of intestinal CD4+ T cells is not predictive of simian immunodeficiency virus virulence. J Immunol 2007;179(5):303546.

42. Beer B, Scherer J, zur Megede J, et al. Lack of dichotomy between virus load of peripheral blood and lymph nodes during long-term simian immunodeficiency virus infection of African green monkeys. Virology 1996;219(2):367-75.

43. Chakrabarti L, Cumont MC, Montagnier L, Hurtrel B. Variable course of primary simian immunodeficiency virus infection in lymph nodes: relation to disease progression. J Virol 1994;68(10):6634-43.

44. Koopman G, Haaksma AG, ten Velden J, Hack CE, Heeney JL. The relative resistance of HIV type 1-infected chimpanzees to AIDS correlates with the maintenance of follicular architecture and the absence of infiltration by CD8+ cytotoxic $\mathrm{T}$ lymphocytes. AIDS Res Hum Retroviruses 1999;15(4):365-73.

45. Pantaleo G, Graziosi C, Demarest JF, et al. HIV infection is active and progressive in lymphoid tissue during the clinically latent stage of disease. Nature 1993;362(6418):355-8.

46. Holznagel E, Norley S, Holzammer S, Coulibaly C, Kurth R. Immunological changes in simian immunodeficiency virus (SIV(agm))-infected African green monkeys (AGM): expanded cytotoxic $\mathrm{T}$ lymphocyte, natural killer and $\mathrm{B}$ cell subsets in the natural host of SIV(agm). J Gen Virol 2002;83(Pt 3):631-40.

47. Pandrea I, Apetrei C, Gordon S, et al. Paucity of CD4+CCR5+ T cells is a typical feature of natural SIV hosts. Blood 2007;109(3):1069-76.

48. Mandl JN, Barry AP, Vanderford TH, et al. Divergent TLR7 and TLR9 signaling and type I interferon production distinguish pathogenic and nonpathogenic AIDS virus infections. Nat Med 2008;14(10):1077-87.

49. Deng HK, Unutmaz D, KewalRamani VN, Littman DR. Expression cloning of new receptors used by simian and human immunodeficiency viruses. Nature 1997;388(6639):296-300. 
50. Chen Z, Gettie A, Ho DD, Marx PA. Primary SIVsm isolates use the CCR5 coreceptor from sooty mangabeys naturally infected in west Africa: a comparison of coreceptor usage of primary SIVsm, HIV-2, and SIVmac. Virology 1998;246(1):113-24.

51. Kuhmann SE, Madani N, Diop OM, et al. Frequent substitution polymorphisms in African green monkey CCR5 cluster at critical sites for infections by simian immunodeficiency virus SIVagm, implying ancient virus-host coevolution. J Virol 2001;75(18):8449-60.

52. Owen SM, Masciotra S, Novembre F, et al. Simian immunodeficiency viruses of diverse origin can use CXCR4 as a coreceptor for entry into human cells. J Virol 2000;74(12):5702-8.

53. Edinger AL, Amedee A, Miller K, et al. Differential utilization of CCR5 by macrophage and $\mathrm{T}$ cell tropic simian immunodeficiency virus strains. Proc Natl Acad Sci U S A 1997;94(8):4005-10.

54. Schols D, De Clercq E. The simian immunodeficiency virus mnd(GB-1) strain uses CXCR4, not CCR5, as coreceptor for entry in human cells. J Gen Virol 1998;79(Pt 9):2203-5. carry the potential to infect CD4(-) cells expressing CCR5 or CXCR4 in vivo.

55. Marx PA, Chen Z. The function of simian chemokine receptors in the replication of SIV. Semin Immunol 1998;10(3):215-23.

56. Mattapallil JJ, Douek DC, Hill B, et al. Massive infection and loss of memory CD4+ T cells in multiple tissues during acute SIV infection. Nature 2005;434(7037):1093-7.

57. Silvestri G, Paiardini M, Pandrea I, Lederman MM, Sodora DL. Understanding the benign nature of SIV infection in natural hosts. J Clin Invest 2007;117(11):3148-54.

58. Pandrea I, Ribeiro RM, Gautam R, et al. Simian immunodeficiency virus SIVagm dynamics in African green monkeys. J Virol 2008;82(7):3713-24.

59. Li Q, Duan L, Estes JD, et al. Peak SIV replication in resting memory CD4+ T cells depletes gut lamina propria CD4+ T cells. Nature 2005;434(7037):1148-52.

60. Ploquin MJ, Diop OM, Sol-Foulon N, et al. DC-SIGN from African green monkeys is expressed in lymph nodes and mediates infection in trans of simian immunodeficiency virus SIVagm. J Virol 2004;78(2):798-810.

61. Hartung S, Boller K, Cichutek K, Norley SG, Kurth R. Quantitation of a lentivirus in its natural host: simian immunodeficiency virus in African green monkeys. J Virol 1992;66(4):2143-9.

62. Konig RR, Flory E, Steidl S, et al. Engineered CD4- and CXCR4-using simian immunodeficiency virus from African green monkeys is neutralization sensitive and replicates in nonstimulated lymphocytes. J Virol 2002;76(21):10627-36.

63. Dehghani H, Brown CR, Plishka R, Buckler-White A, Hirsch VM. The ITAM in Nef influences acute pathogenesis of AIDS-inducing simian immunodeficiency viruses SIVsm and SIVagm without altering kinetics or extent of viremia. J Virol 2002;76(9):4379-89.

64. Klatt NR, Villinger F, Bostik P, et al. Availability of activated CD4+ T cells dictates the level of viremia in naturally SIV-infected sooty mangabeys. J Clin Invest 2008;118(6):2039-49.

65. Kornfeld C, Ploquin MJ, Pandrea I, et al. Antiinflammatory profiles during primary SIV infection in African green monkeys are associated with protection against AIDS. J Clin Invest 2005;115(4):1082-91.

66. Muthukumar A, Zhou D, Paiardini M, et al. Timely triggering of homeostatic mechanisms involved in the regulation of T-cell levels in SIVsm-infected sooty mangabeys. Blood 2005;106(12):3839-45. 
67. Chakrabarti LA, Lewin SR, Zhang L, et al. Normal T-cell turnover in sooty mangabeys harboring active simian immunodeficiency virus infection. J Virol 2000;74(3):1209-23.

68. Gordon SN, Klatt NR, Bosinger SE, et al. Severe depletion of mucosal CD4+ T cells in AIDS-free simian immunodeficiency virus-infected sooty mangabeys. J Immunol 2007;179(5):3026-34.

69. Veazey RS, Lackner AA. HIV swiftly guts the immune system. Nat Med 2005;11(5):469-70.

70. Zeitz M, Ullrich R, Schneider T, Kewenig S, Riecken E. Mucosal immunodeficiency in HIV/SIV infection. Pathobiology 1998;66(3-4):151-7.

71. Silvestri G, Sodora DL, Koup RA, et al. Nonpathogenic SIV infection of sooty mangabeys is characterized by limited bystander immunopathology despite chronic high-level viremia. Immunity 2003;18(3):441-52.

72. Kaur A, Di Mascio M, Barabasz A, et al. Dynamics of T- and B-lymphocyte turnover in a natural host of simian immunodeficiency virus. J Virol 2008;82(3):1084-93.

73. Estaquier J, Idziorek $\mathrm{T}$, de Bels $\mathrm{F}$, et al. Programmed cell death and AIDS: significance of T-cell apoptosis in pathogenic and nonpathogenic primate lentiviral infections. Proc Natl Acad Sci U S A 1994;91(20):9431-5.

74. Cecchinato V, Trindade CJ, Laurence A, et al. Altered balance between Th17 and Th1 cells at mucosal sites predicts AIDS progression in simian immunodeficiency virusinfected macaques. Mucosal Immunol 2008;1(4):279-288.

75. Milush JM, Reeves JD, Gordon SN, et al. Virally induced CD4+ T cell depletion is not sufficient to induce AIDS in a natural host. J Immunol 2007;179(5):3047-56.

76. Picker LJ, Hagen SI, Lum R, et al. Insufficient production and tissue delivery of $\mathrm{CD} 4+$ memory $\mathrm{T}$ cells in rapidly progressive simian immunodeficiency virus infection. J Exp Med 2004;200(10):1299-314.

77. Ling B, Veazey RS, Hart M, et al. Early restoration of mucosal CD4 memory CCR5 T cells in the gut of SIV-infected rhesus predicts long term non-progression. Aids 2007;21(18):2377-85.

78. Verhoeven D, Sankaran S, Silvey M, Dandekar S. Antiviral therapy during primary simian immunodeficiency virus infection fails to prevent acute loss of CD4+ T cells in gut mucosa but enhances their rapid restoration through central memory T cells. $\mathrm{J}$ Virol 2008;82(8):4016-27.

79. Hazenberg MD, Otto SA, van Benthem BH, et al. Persistent immune activation in HIV-1 infection is associated with progression to AIDS. Aids 2003;17(13):1881-8.

80. van Asten L, F. Danisman, S. A. Otto, J. A. Borghans, M. D. Hazenberg, R. A. Coutinho, M. Prins, and F. Miedema. . Pre-seroconversion immune status predicts the rate of CD4 T cell decline following HIV infection. . Aids 18:1885-93. 2004.

81. Liu Z, Cumberland WG, Hultin LE, et al. Elevated CD38 antigen expression on CD8+ $\mathrm{T}$ cells is a stronger marker for the risk of chronic HIV disease progression to AIDS and death in the Multicenter AIDS Cohort Study than CD4+ cell count, soluble immune activation markers, or combinations of HLA-DR and CD38 expression. J Acquir Immune Defic Syndr Hum Retrovirol 1997;16(2):83-92.

82. Giorgi JV, Hultin LE, McKeating JA, et al. Shorter survival in advanced human immunodeficiency virus type 1 infection is more closely associated with $\mathrm{T}$ lymphocyte activation than with plasma virus burden or virus chemokine coreceptor usage. J Infect Dis 1999;179(4):859-70.

83. Pandrea I, Onanga R, Kornfeld C, et al. High levels of SIVmnd-1 replication in chronically infected Mandrillus sphinx. Virology 2003;317(1):119-27. 
84. Brenchley JM, Price DA, Schacker TW, et al. Microbial translocation is a cause of systemic immune activation in chronic HIV infection. Nat Med 2006;12(12):1365-71.

85. Park H, Li Z, Yang XO, et al. A distinct lineage of CD4 T cells regulates tissue inflammation by producing interleukin 17. Nat Immunol 2005;6(11):1133-41.

86. Liang SC, Tan XY, Luxenberg DP, et al. Interleukin (IL)-22 and IL-17 are coexpressed by Th17 cells and cooperatively enhance expression of antimicrobial peptides. J Exp Med 2006;203(10):2271-9.

87. Raffatellu M, Santos RL, Verhoeven DE, et al. Simian immunodeficiency virusinduced mucosal interleukin-17 deficiency promotes Salmonella dissemination from the gut. Nat Med 2008;14(4):421-8.

88. Li Q, Estes JD, Duan L, et al. Simian immunodeficiency virus-induced intestinal cell apoptosis is the underlying mechanism of the regenerative enteropathy of early infection. J Infect Dis 2008;197(3):420-9.

89. Akira S, Uematsu S, Takeuchi O. Pathogen recognition and innate immunity. Cell 2006;124(4):783-801.

90. Alexopoulou L, Holt AC, Medzhitov R, Flavell RA. Recognition of double-stranded RNA and activation of NF-kappaB by Toll-like receptor 3. Nature 2001;413(6857):732-8.

91. Hornung V, Rothenfusser S, Britsch S, et al. Quantitative expression of toll-like receptor 1-10 mRNA in cellular subsets of human peripheral blood mononuclear cells and sensitivity to CpG oligodeoxynucleotides. J Immunol 2002;168(9):4531-7.

92. Diebold SS, Kaisho T, Hemmi H, Akira S, Reis e Sousa C. Innate antiviral responses by means of TLR7-mediated recognition of single-stranded RNA. Science 2004;303(5663):1529-31.

93. Heil F, Hemmi H, Hochrein $\mathrm{H}$, et al. Species-specific recognition of single-stranded RNA via toll-like receptor 7 and 8. Science 2004;303(5663):1526-9.

94. Hemmi H, Takeuchi O, Kawai T, et al. A Toll-like receptor recognizes bacterial DNA. Nature 2000;408(6813):740-5.

95. Kadowaki N, Ho S, Antonenko S, et al. Subsets of human dendritic cell precursors express different toll-like receptors and respond to different microbial antigens. J Exp Med 2001;194(6):863-9.

96. Beignon AS, McKenna K, Skoberne M, et al. Endocytosis of HIV-1 activates plasmacytoid dendritic cells via Toll-like receptor-viral RNA interactions. J Clin Invest 2005;115(11):3265-75.

97. Lester RT, Yao XD, Ball TB, et al. Toll-like receptor expression and responsiveness are increased in viraemic HIV-1 infection. Aids 2008;22(6):685-94.

98. Sanghavi SK, Reinhart TA. Increased expression of TLR3 in lymph nodes during simian immunodeficiency virus infection: implications for inflammation and immunodeficiency. J Immunol 2005;175(8):5314-23.

99. George MD, Verhoeven D, McBride Z, Dandekar S. Gene expression profiling of gut mucosa and mesenteric lymph nodes in simian immunodeficiency virus-infected macaques with divergent disease course. J Med Primatol 2006;35(4-5):261-9.

100. Bosinger SE, Hosiawa KA, Cameron MJ, et al. Gene expression profiling of host response in models of acute HIV infection. J Immunol 2004;173(11):6858-63.

101. Martinelli E, Cicala C, Van Ryk D, et al. HIV-1 gp120 inhibits TLR9-mediated activation and IFN-\{alpha\} secretion in plasmacytoid dendritic cells. Proc Natl Acad Sci U S A 2007;104(9):3396-401.

102. Bafica A, Scanga CA, Schito M, Chaussabel D, Sher A. Influence of coinfecting pathogens on HIV expression: evidence for a role of Toll-like receptors. J Immunol 2004;172(12):7229-34. 
103. Diop OM, Ploquin MJ, Mortara L, et al. Plasmacytoid dendritic cell dynamics and alpha interferon production during Simian immunodeficiency virus infection with a nonpathogenic outcome. J Virol 2008;82(11):5145-52.

104. Ploquin MJ, Desoutter JF, Santos PR, et al. Distinct expression profiles of TGF-beta1 signaling mediators in pathogenic SIVmac and non-pathogenic SIVagm infections. Retrovirology 2006;3:37.

105. Bostik P, Watkins M, Villinger F, Ansari AA. Genetic analysis of cytokine promoters in nonhuman primates: implications for Th1/Th2 profile characteristics and SIV disease pathogenesis. Clin Dev Immunol 2004;11(1):35-44.

106. Malleret B, Maneglier B, Karlsson I, et al. Primary infection with simian immunodeficiency virus: plasmacytoid dendritic cell homing to lymph nodes, type I IFN, and immune suppression. Blood 2008.

107. Keir ME, Stoddart CA, Linquist-Stepps V, Moreno ME, McCune JM. IFN-alpha secretion by type 2 predendritic cells up-regulates MHC class I in the HIV-1-infected thymus. J Immunol 2002;168(1):325-31.

108. Herbeuval JP, Shearer GM. HIV-1 immunopathogenesis: how good interferon turns bad. Clin Immunol 2007;123(2):121-8.

109. Estes JD, Li Q, Reynolds MR, et al. Premature induction of an immunosuppressive regulatory $\mathrm{T}$ cell response during acute simian immunodeficiency virus infection. $\mathrm{J}$ Infect Dis 2006;193(5):703-12.

110. Cumont MC, Monceaux V, Viollet L, et al. TGF-beta in intestinal lymphoid organs contributes to the death of armed effector CD8 $\mathrm{T}$ cells and is associated with the absence of virus containment in rhesus macaques infected with the simian immunodeficiency virus. Cell Death Differ 2007;14(10):1747-58.

111. Trautmann L, Chomont N, Sekaly RP. [Inhibition of the PD-1 pathway restores the effector function of HIV-specific T cells]. Med Sci (Paris) 2007;23(1):24-5.

112. Epple HJ, Loddenkemper C, Kunkel D, et al. Mucosal but not peripheral FOXP3+ regulatory $\mathrm{T}$ cells are highly increased in untreated HIV infection and normalize after suppressive HAART. Blood 2006;108(9):3072-8.

113. Coleman CA, Muller-Trutwin MC, Apetrei C, Pandrea I. T regulatory cells: aid or hindrance in the clearance of disease? J Cell Mol Med 2007;11(6):1291-325.

114. Lund JM, Hsing L, Pham TT, Rudensky AY. Coordination of early protective immunity to viral infection by regulatory T cells. Science 2008;320(5880):1220-4.

115. Karlsson I, Malleret B, Brochard P, et al. FoxP3+ CD25+ CD8+ T-cell induction during primary simian immunodeficiency virus infection in cynomolgus macaques correlates with low CD4+ T-cell activation and high viral load. J Virol 2007;81(24):13444-55.

116. Fehervari Z, Sakaguchi S. Control of Foxp3+ CD25+CD4+ regulatory cell activation and function by dendritic cells. Int Immunol 2004;16(12):1769-80.

117. Wang J, Ioan-Facsinay A, van der Voort EI, Huizinga TW, Toes RE. Transient expression of FOXP3 in human activated nonregulatory CD4+ T cells. Eur J Immunol 2007;37(1):129-38.

118. Pereira LE, Villinger F, Onlamoon N, et al. Simian Immunodeficiency Virus (SIV) Infection Influences the Level and Function of Regulatory T Cells in SIV-Infected Rhesus Macaques but Not SIV-Infected Sooty Mangabeys. J Virol 2007;81(9):444556.

119. Sumpter B, Dunham R, Gordon S, et al. Correlates of preserved CD4(+) T cell homeostasis during natural, nonpathogenic simian immunodeficiency virus infection of sooty mangabeys: implications for AIDS pathogenesis. $\mathrm{J}$ Immunol 2007;178(3):1680-91. 
120. Khoury SJ, Sayegh MH. The roles of the new negative T cell costimulatory pathways in regulating autoimmunity. Immunity 2004;20(5):529-38.

121. Keir ME, Freeman GJ, Sharpe AH. PD-1 regulates self-reactive CD8+ T cell responses to antigen in lymph nodes and tissues. J Immunol 2007;179(8):5064-70. 


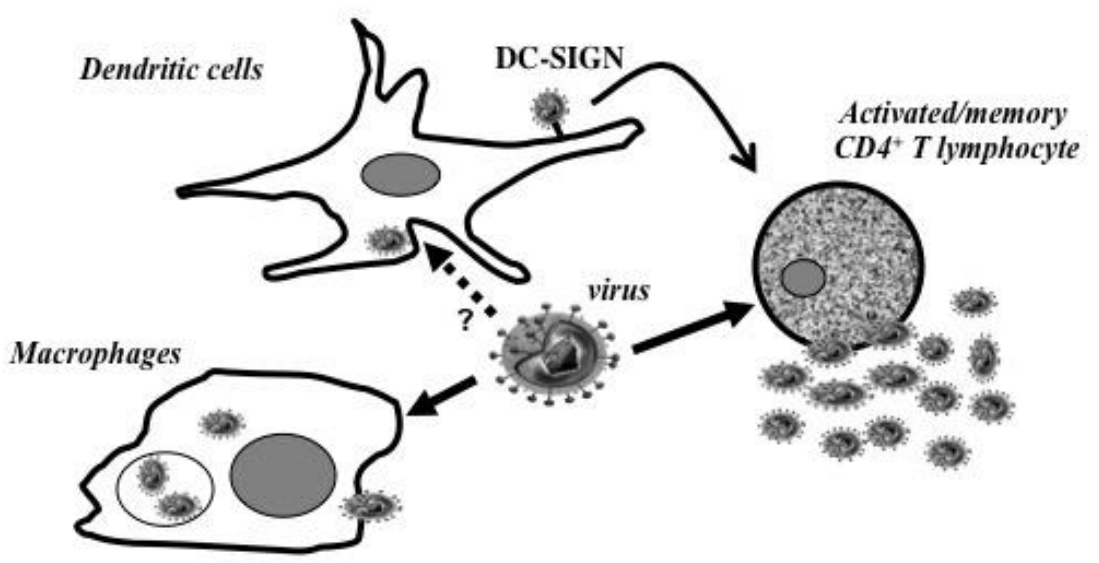

Fig 1.

Fig 1. Cellular targets of SIV in non pathogenic infection.

SIVs from African NHPs replicate predominantly in activated/memory T CD4 ${ }^{+}$lymphocytes. Macrophages can also be infected. No data are available about the susceptibility of African NHP DCs to SIV infection (dotted arrow). DC-SIGN expressed on AGM MDDC can efficiently transfer SIVagm to T cells and this enhances T cell infection. 

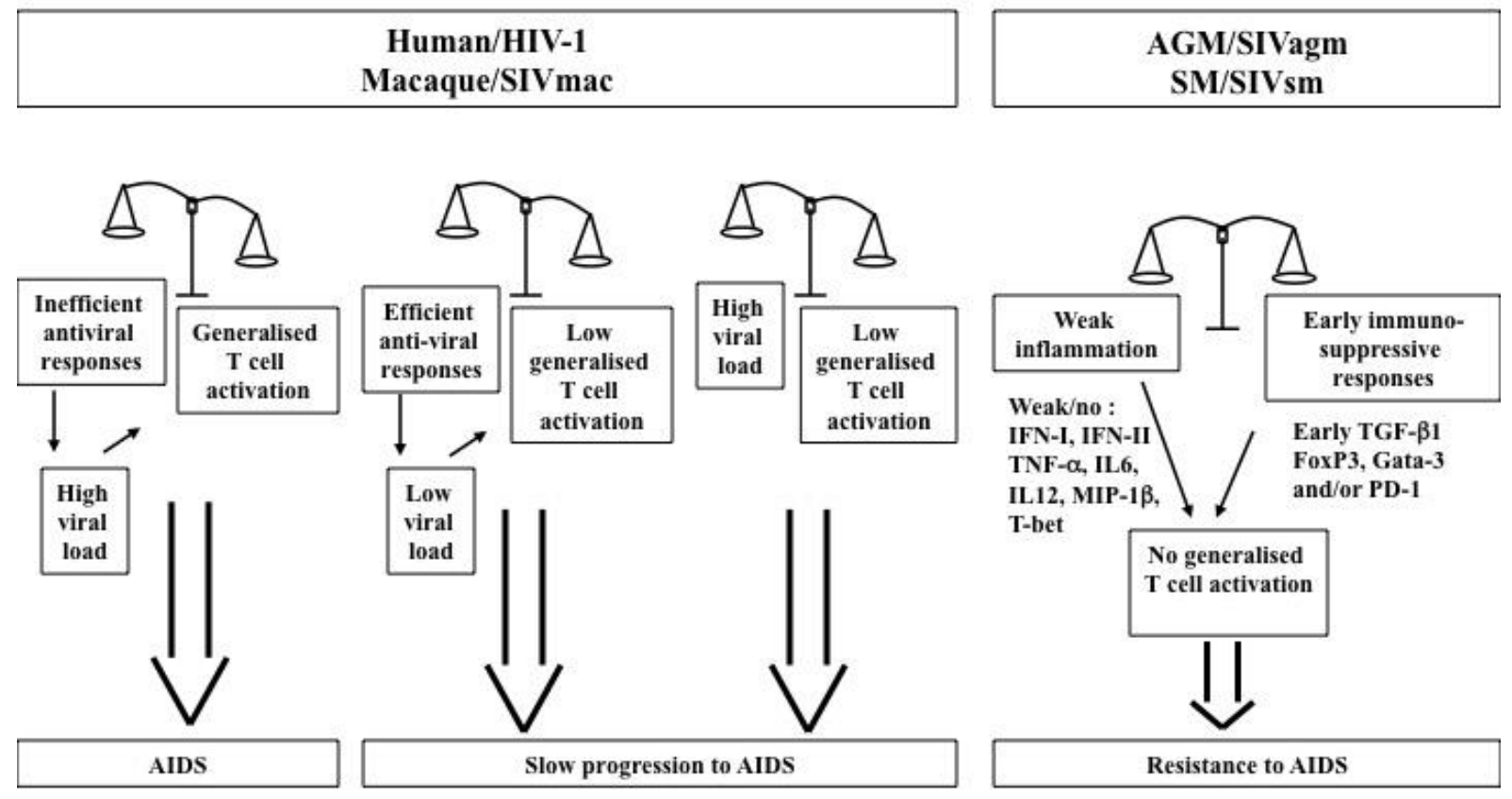

Fig 2

Fig 2: Hypothetic model on the mechanisms responsible for the distinct outcomes of HIV-1/SIV infections. 


\begin{tabular}{|c|c|c|c|c|}
\hline Phase & acute & chronic & acute & chronic \\
\hline Mutation rate in vivo & + & + & + & + \\
\hline Viral load & + & + & + & + \\
\hline \multicolumn{5}{|l|}{ Depletion of $\mathrm{CD}^{+} \mathrm{T}$ cells } \\
\hline blood & + & + & + & - \\
\hline peripheral LN & + & + & + & - \\
\hline gut & + & + & + & + \\
\hline Adaptative antiviral responses & + & + & + & + \\
\hline \multicolumn{5}{|l|}{ T cell activation } \\
\hline blood & + & + & + & - \\
\hline peripheral LN & + & + & + & - \\
\hline gut & + & + & + & - \\
\hline $\mathrm{CD}^{+} \mathrm{T}$ cell apoptosis & + & + & - & - \\
\hline Immune activation profile & \multicolumn{2}{|c|}{ pro-inflammatory } & \multicolumn{2}{|c|}{ anti-inflammatory } \\
\hline
\end{tabular}

Tab. 1: Main characteristics of non-pathogenic SIV versus pathogenic HIV-1/SIV infections during the acute and chronic phase.

Parameters are presented as qualitative. The references associated with the data are cited in the text. 


\begin{tabular}{|c|c|c|c|c|c|}
\hline $\begin{array}{l}\text { infection } \\
\text { phase }\end{array}$ & $\begin{array}{c}\text { outcome of } \\
\text { the } \\
\text { infection }\end{array}$ & species & $\begin{array}{c}\text { number of } \\
\text { animals }\end{array}$ & $\begin{array}{c}\text { viral RNA } \\
\text { positive } \\
\text { cells \# }\end{array}$ & References \\
\hline \multirow{8}{*}{ primary } & & & $\overline{1}$ & $25^{*}$ & $\overline{(42)^{11}}$ \\
\hline & non & AGM & 6 & 12 & $(22)^{n}$ \\
\hline & $\begin{array}{c}\text { patnogenic } \\
--------1\end{array}$ & S- & 5 & 픈. & $(4)$ \\
\hline & & macaque & & & \\
\hline & \multirow{4}{*}{ pathogenic } & - slow/intermediate & 8 & $50-100$ & $(43)^{\|}$ \\
\hline & & & 8 & 15 & $(22)^{\Perp}$ \\
\hline & & - rapid progressors & 6 & 102 & $(22)^{\|}$ \\
\hline & & SIVagmver90/ Pt mac & 8 & $5-80 *$ & $(9)^{\|}$ \\
\hline \multirow{5}{*}{ chronic } & non- & AGM & 19 & $<1$ & $\begin{array}{l}(22,31,42, \\
\text { unpublished) }\end{array}$ \\
\hline & patnogenic & SM & $\underline{2}$ & $\underline{1}-\underline{-}$ & $-\ldots(28)$ \\
\hline & \multirow{3}{*}{ pathogenic } & $\begin{array}{l}\text { macaque } \\
\text { - slow/intermediate } \\
\text { progressors }\end{array}$ & 10 & $1-4^{n}$ & $(22,43)$ \\
\hline & & - rapid progressors & 14 & 1-100 & $(22,43)$ \\
\hline & & SI Vagmver90/ Pt mac & 8 & $2-40 *$ & (9)" \\
\hline
\end{tabular}

Tab. 2: Viral load in Lymph nodes during SIV infections.

The table assembles data reported in the litterature on viral load in peripheral LNs during nonpathogenic SIVagm and SIVsm infection. A few representative data in SIVmac infection are shown for comparison. A low viral load is observed in LNs during the chronic phase of non pathogenic SIVagm infection. \# Data are given per $\mathrm{mm}^{2}$ except those values marked with an asteriks (*) that designs numbers per analysed region. 


\begin{tabular}{llll} 
co-receptor & HIV & SIV & \\
\hline CCR5 & +++ & +++ & SIVmac, SIVsm, SIVagm,SIVmnd, ... \\
CXCR4 & +++ & $-(++)$ & SIVagm.sab, SIVmnd-1c, ... \\
Bob/GPR15 & + & ++ & SIVmac, SIVsm, ... \\
Bonzo/STLR33 & + & ++ & SIvagm, ... \\
CCR2b & + & + & SIVrcm \\
CCR3 & + & + & SIVsm \\
CCR8 & + & + & SIVmac, SIVsm \\
CX3CR1/V28 & + & + & SIVsm, SIVst \\
GPR1 & + & + & SIVmac \\
Apj & + & - & \\
CCR9 & + & - & \\
CMKRL1 & + & - & \\
ChemR23 & + & - & \\
US28 & + & - & \\
X & - & + & SIVagm \\
trans-receptor & & & \\
DC-SIGN & ++ & ++ & SIVmac, SIVagm \\
\hline
\end{tabular}

Tab. 3: HIV-1/SIV co-and trans-receptors.

CCR5 is the major co-receptor for SIVs from African NHP's except for SIVrcm. SIVsm and SIVagm generally are also able to use Bob and Bonzo. Some SIVagm.sab isolates have in addition a tropism for CXCR4. The other co-receptors are used only rarely. X designs non identified co-receptors. The fourth column gives examples of SIV, which use the corresponding co-receptor. 


\begin{tabular}{|c|c|c|c|c|c|}
\hline & marker & early acute & chronic & early acute & chronic \\
\hline \multirow{5}{*}{$\begin{array}{c}\text { Cytokines } \\
\text { (blood, LN, } \\
\text { mucosa) }\end{array}$} & Pro-inflammatory & & & & \\
\hline & IFN (alpha, gamma) & + & + & \pm & - \\
\hline & $\begin{array}{c}\text { TNF-a, IL-6, IL-12, } \\
\text { MIP-1a, MIP-1b }\end{array}$ & + & + & - & - \\
\hline & Anti-inflammatory & & & & \\
\hline & IL-10, TGF-b1 & + & + & + & - \\
\hline \multirow{4}{*}{ T cell profile } & t-bet & + & nd & - & nd \\
\hline & gata-3 & + & nd & + & nd \\
\hline & foxP3 & + & + & + & nd \\
\hline & PD-1 & - & + & + & - \\
\hline
\end{tabular}

Tab. 4: Inflammatory profiles during non-pathogenic and pathogenic SIV infections.

The table summarizes schematically the data of the literature. The references corresponding to the data listed in the table are cited in the text. Parameters are presented as qualitative. T-bet and Gata-3 are transcription factors essential for the induction of, respectively, Th1 and Th2 responses. FoxP 3 is a transcription factor expressed by $\mathrm{CD} 25^{+}$Treg. Nd: non determined. 